Research Article

\title{
Compliance to prescribed medication among patients in a tertiary care hospital using Morisky-Green test
}

\author{
Megaravalli R. Manasa ${ }^{1}$, Josephine Kennedy Preethy ${ }^{1}$, Idoor D. Sachin ${ }^{2}$
}

\begin{abstract}
${ }^{1}$ Department of Pharmacology, Pushpagiri institute of medical sciences and research centre, Thiruvalla, Kerala, India ${ }^{2}$ Department of General Surgery, Pushpagiri Institute of Medical Sciences \& Research Centre, Tiruvalla, Kerala
\end{abstract}

Received: 07 December 2015 Accepted: 21 December 2015

\section{*Correspondence to:}

Dr. Megaravalli R Manasa, Email:dr.manasamr@gmail.com

Copyright: (C) the author(s), publisher and licensee Medip Academy. This is an openaccess article distributed under the terms of the Creative Commons Attribution NonCommercial License, which permits unrestricted noncommercial use, distribution, and reproduction in any medium, provided the original work is properly cited.

\begin{abstract}
Background: Compliance to medication is an important factor in the success of any treatment. It also reduces the health care cost. The objective of the study was to examine compliance of patients to treatment and investigate reasons for such compliance and to quantify non adherence to medications and raise awareness about such factors.

Methods: A prospective cross sectional questionnaire based study was conducted in 300 patients during three month period in 2013. The inclusion criteria was patients aged $>18$ years of both sexes and on treatment for diseases like asthma, hypertension, diabetes and coronary artery disease. Compliance was assessed using Morisky-Green test. Data was analysed by SPSS 19 and Chi square test was used to analyse the contingency tables and $\mathrm{P} \leq 0.05$ was considered significant.

Results: The study revealed a compliance of $40.7 \%$. There was statistically significant association between compliance and younger age, lower level of education, low socio-economic status, acute disease and presence of comorbidity. The common causes for non-compliance were forgetfulness and side effects of drugs.

Conclusions: More than half of the study subjects were non-compliant. Hence a conscious effort is needed to educate the patients regarding their disease and the importance of compliance to treatment.
\end{abstract}

Keywords: Compliance, Medication, Morisky-Green test

\section{INTRODUCTION}

Non-compliance to treatment is a major hindrance to the effective delivery of health care worldwide. The World Health Organization in 2003 estimated that only about $50 \%$ of patients with chronic diseases in developed countries are compliant. The adherence rates for preventative therapies are even lower, and are about $28 \%$ in developing countries. ${ }^{1}$ WHO defined compliance as, "the extent to which a patient takes medication, follows a diet, and/or executes lifestyle changes as per the recommendations of a health care provider. ${ }^{1,2}$ Compliance involves taking the prescribed medications, attending follow-up appointments and following the recommended lifestyle modifications. ${ }^{3-5}$
Non-compliance affects patient health, and the society as a whole as it causes complications like unsuccessful treatment of chronic diseases, untreated psychiatric illness, formation of resistant infections etc. ${ }^{1}$ Noncompliance is the most important basis of treatment failure. The consequences of non-compliance increase the financial costs of public health services dramatically. ${ }^{6,7}$ Low rates of compliance to treatment for asthma, diabetes, and hypertension contribute substantially to the human and economic burden. ${ }^{1}$

Very few studies have been done to understand factors influencing non-adherence to treatment even though poor compliance is a well-recognized problem in daily practice. ${ }^{8}$ Most of the studies have been conducted in developed countries. Very few studies have been done in 
India. ${ }^{9}$ Furthermore, criteria to assess non-adherence are often arbitrary and not linked to clinical outcomes.

The present study was conducted based on the following objectives:

1. To study the compliance of patients to treatment and investigate factors determining such compliance.

2. To quantify non adherence to medications and raise awareness of such factors.

\section{METHODS}

A prospective cross-sectional study was conducted on 300 patients attending Pushpagiri Institute of Medical sciences and research centre, Tiruvalla, Kerala. The study was done for a period of 3 months from June 2013 to august 2013.

Patients were selected based on the following criteria:

1. Patients aged above 18 years of both sexes.

2. Patients known to be on medications due to various diseases such as Coronary Artery Disease, Diabetes, Asthma, hypertension etc.

The purpose of the study was explained to each patient. The patients who agreed to be a part of the study and gave a written informed consent were selected. The study was approved by the Institutional ethics committee.

Data was obtained from patients by a detailed structured questionnaire which was filled for each patient by the researcher.

The questionnaire consisted of - :

1. General information in which patient was classified into: Old/Young, Male/Female, Acute /Chronic disease, socio economic statuslow/intermediate/high, and education level $<10$ th std. or $>10$ std.

2. Specific information regarding compliance Morisky-Green test was used for evaluating patient's compliance to medications; the Morisky-Green test consists of the following questions:

a) Have you ever forgotten to take medicine?

b) Are you sometimes negligent with regard to your medicine hours?

c) Do you skip your medicines when you are feeling well?

d) When you feel badly due to the medicine, do you skip it?

According to the protocol of the Morisky-Green test, patients were considered compliant to the treatment when they scored the maximum score of 4 points, and patients were considered non-compliant when they scored 3 points or less. ${ }^{3,10,11}$
3. Patients who were non-compliant to treatment were evaluated in detail and the reasons for noncompliance such as forgetfulness/wasn't reminded to take medication, disbelief that drug is necessary or is helping, fear of addiction, experienced actual side effects, belief that medication would have a negative impact on performance of daily activities, desire to save money/poverty, confused by instructions, overwhelmed by number of drugs prescribed, difficulty in opening medication container and difficulty in swallowing medication were determined.

Data was analysed by SPSS 19. Chi-square test was used in the analysis of contingency tables. $\mathrm{P} \leq 0.05$ was considered significant.

\section{RESULTS}

Table 1: Number of individuals compliant and noncompliant.

\begin{tabular}{|lll|}
\hline & Number (\%) & Mean age (S.D.) \\
\hline Compliant & $122(40.7)$ & $46.75(13.6)$ \\
\hline Non-compliant & $178(59.3)$ & $59.87(19.8)$ \\
\hline
\end{tabular}

Among the 300 patients studied, 122 (4.7\%) were found to be compliant to the medications prescribed. The rest $178(59.3 \%)$ were non- compliant. The mean age of patients who were non-compliant was 59.87 years (SD 19.8) and that of those who were compliant was 46.75 years (SD 13.6) which was lower than the non-compliant group (Table 1).

Out of 300 patients, 193(64.3\%) were females and 107 (35.7\%) were males. Among the 193 female patients, 110 $(56.9 \%)$ were non-compliant and 83 (43\%) were compliant. Among the 107 male patients, 68 (63.5\%) were non-compliant and 39 (36.4\%) were compliant. The gender distributions among the compliant and noncompliant groups were not significantly different (Table 2).

33 patients had education level lower than $10^{\text {th }}$ standard and 267 patients had education level higher than $10^{\text {th }}$ standard. Among the 33 patients with education level lower than $10^{\text {th }}$ standard, $4(12.1 \%)$ patients were noncompliant and $29(87.8 \%)$ were compliant. Out of the 267 patients who had education level higher than 10th standard, $174(65.2 \%)$ were non-compliant and 93 (34.8\%) were compliant. This difference was statistically significant $(\mathrm{P}<0.0001)$ as compliance was better in patients with education level lower than $10^{\text {th }}$ standard. (Table 2)

$219 \quad(73 \%)$ study subjects had intermediate socioeconomic status, $65(21.7 \%)$ low socioeconomic status and $16(5.3 \%)$ high socioeconomic status. Compliance was found to be statistically significant 
among patients who had low socioeconomic status $(\mathrm{P}<$ 0.001) (Table 2).

$53(17.7 \%)$ patients out of 300 had acute disease and 247

$(82.3 \%)$ had chronic disease. Compliance was significantly more in patients having acute disease $(\mathrm{P}<$ 0.0001) (Table 3).

Table 2: Compliance rate by Morisky Green test according to socio-demographic factors.

\begin{tabular}{|c|c|c|c|c|c|}
\hline & $\begin{array}{l}\text { Compliant (\%) } \\
\mathrm{N}=122\end{array}$ & $\begin{array}{l}\text { Non-compliant }(\%) \\
\mathbf{N}=\mathbf{1 7 8}\end{array}$ & $\begin{array}{l}\text { Total }(\%) \\
\mathbf{N}=\mathbf{3 0 0}\end{array}$ & Chi square & $P$ value \\
\hline \multicolumn{6}{|l|}{ Gender } \\
\hline Male & 39 (36.4) & 68 (63.5) & $107(100)$ & \multirow{2}{*}{1.22} & \multirow{2}{*}{0.26} \\
\hline Female & $83(43)$ & $110(56.9)$ & $193(100)$ & & \\
\hline \multicolumn{6}{|c|}{ Level of education } \\
\hline$<10$ std & $29(87.8)$ & $4(12.1)$ & $33(100)$ & \multirow{2}{*}{34.25} & \multirow{2}{*}{$<0.0001$} \\
\hline$>10$ std & 93 (34.8) & $174(65.2)$ & $267(100)$ & & \\
\hline \multicolumn{6}{|c|}{ Socio-economic status } \\
\hline Low & $39(60)$ & $26(40)$ & 65 (100) & \multirow{3}{*}{13.6} & \multirow{3}{*}{$<0.001$} \\
\hline Intermediate & $79(36.1)$ & $140(63.9)$ & $219(100)$ & & \\
\hline High & $4(25)$ & $12(75)$ & $16(100)$ & & \\
\hline
\end{tabular}

Table 3: Compliance in acute and chronic disease.

\begin{tabular}{|llllll|} 
& $\begin{array}{l}\text { Compliant }(\%) \\
\mathbf{N}=\mathbf{1 2 2}\end{array}$ & $\begin{array}{l}\text { Non-compliant }(\%) \\
\mathbf{N}=\mathbf{1 7 8}\end{array}$ & $\begin{array}{l}\text { Total }(\%) \\
\mathbf{N}=\mathbf{3 0 0}\end{array}$ & Chi square & P value \\
\cline { 1 - 3 } Acute disease & $35(66)$ & $18(33.9)$ & $53(100)$ & 17.17 & $<0.0001$ \\
\hline Chronic disease & $87(35.2)$ & $160(64.8)$ & $247(100)$ & \\
\hline
\end{tabular}

Table 4: Compliance among patients suffering from various diseases.

\begin{tabular}{|lllll|}
\hline & Compliant & Non-compliant & Total & $\%$ non-compliant \\
\hline Asthma & 22 & 20 & 42 & 47.61 \\
\hline CAD & 21 & 81 & 102 & 79.4 \\
\hline DM & 55 & 50 & 105 & 47.61 \\
\hline HTN & 16 & 13 & 29 & 44.8 \\
\hline DM, HTN & 1 & 1 & 2 & 50 \\
\hline DM, CAD & 2 & 8 & 10 & 80 \\
\hline HTN, CAD & 5 & 3 & 8 & 37.5 \\
\hline HTN, Asthma & 0 & 1 & 1 & 100 \\
\hline CAD, HTN, DM & 0 & 1 & 1 & 100 \\
\hline Total & 122 & 178 & 300 & 59.33 \\
\hline
\end{tabular}

$14 \%$ of the patients were suffering from Asthma, 34\% from Coronary artery disease, $35 \%$ from diabetes, $9.7 \%$ from hypertension and remaining $7.3 \%$ had a combination of above diseases (Table 4).

The reasons for non-compliance were analysed and presented in Table $5.98 \%$ of the non-compliance was due to forgetfulness. $61.2 \%$ of the patients did not inform the doctor about having stopped the medication. $44.4 \%$ of these patients restarted medication on their own once the unusual effects due to medicines had gone. $56 \%$ of the people knew they had done the wrong thing by skipping medication. $63 \%$ of the non-compliant people were not aware of the effects of non-compliance.

\section{DISCUSSION}

Compliance to treatment is a relatively new area of research and not much study has been done in this field, especially in developing countries like India. This was a prospective cross sectional study done on 300 patients in a tertiary health centre among adults above 18 years of 
age of both sexes. The participants in the study were patients on treatment for diabetes mellitus, asthma, hypertension and coronary artery disease. A direct interview by researcher was adopted in the study to increase the accuracy of data collected in comparison to self-completed questionnaires. Morisky-Green test was used for estimation of compliance of subjects to treatment.

Table 5: Reasons for indiscipline.

\begin{tabular}{|c|c|}
\hline $\begin{array}{l}\text { Forgetfulness/Wasn't reminded to take } \\
\text { medication }\end{array}$ & $98 \%$ \\
\hline Experiencing actual side effects & $59.6 \%$ \\
\hline $\begin{array}{l}\text { Belief that medication would have a } \\
\text { negative impact on } \\
\text { performance of daily activities }\end{array}$ & $36 \%$ \\
\hline Fear of addiction & $14 \%$ \\
\hline $\begin{array}{l}\text { Disbelief that drug is necessary or is } \\
\text { helping }\end{array}$ & $10 \%$ \\
\hline Confused by instructions & $2 \%$ \\
\hline Financial reasons & $1 \%$ \\
\hline $\begin{array}{l}\text { Overwhelmed by number of drugs } \\
\text { prescribed }\end{array}$ & $1 \%$ \\
\hline Difficulty opening medication container & $1 \%$ \\
\hline Difficulty swallowing medication & $0.5 \%$ \\
\hline
\end{tabular}

In the present study, there were more female participants than males. The younger patients were more compliant to medication than older patients. This is in agreement with a study done in India and in contrast to a study by Linn et al. ${ }^{9,12}$ The reason for non-compliance in older patients may be due to forgetfulness. About $40.7 \%$ of patients were compliant to their treatment in our study. This is similar to a study done in Hong Kong, lower than other studies done in India, Uganda, Iraq and Palestine and higher than studies done in Mexico and Saudi Arabia. ${ }^{3,6,13-17}$

There was no significant difference in compliance due to gender in our study. Similar results were found in other studies. $^{2,5,18,19}$ Many studies have reported higher compliance in females. ${ }^{20-23}$ Few studies have shown higher compliance in males. ${ }^{14}$

In the present study, compliance was better in patients with lower education level $\left(<10^{\text {th }} \mathrm{std}\right)$. This is similar to other studies. ${ }^{3,9,19,24}$ But some studies reported better compliance in subjects with higher level of education and some studies reported no relation between compliance and level of education. ${ }^{6,20,22}$ Patients with lower level of educational may have more faith in the doctor's advice and hence may be more compliant.

Compliance was higher in patients with low socioeconomic status in our study. This is in agreement with another Indian study. ${ }^{9}$ No such association was reported in other studies. ${ }^{2,25}$
Compliance was significantly higher in acute disease than in chronic disease in this study has found in other studies done in India and Poland. ${ }^{6,26}$ This is in contrast to the findings of other studies. ${ }^{2,3,27}$ Patients with two or more diseases had lower compliance than patients with single disease in our study. This is in contrast to findings of other studies. $^{3,28}$

The patients who were non-compliant to medication were interviewed in detail regarding the causes for noncompliance. Majority of the patients reported forgetfulness as the reason. Others stopped the medication when they experienced side effects or when they felt better. Some believed that it may affect their daily activities adversely.

\section{CONCLUSION}

Our study found that more than half of study subjects are non-compliant to their treatment. Hence a concerted effort is required to educate the patients regarding their disease and the treatment and to monitor the same so that their compliance can be improved.

\section{ACKNOWLEDGEMENTS}

We thank the staff of department of pharmacology of Pushpagiri Institute of medical sciences and research centre, Thiruvalla for their help and support.

Funding: No funding sources

Conflict of interest: None declared

Ethical approval: The study was approved by the Institutional Ethics Committee

\section{REFERENCES}

1. WHO, 2003. Adherence to long-term therapies: evidence for action. Geneva: World Health Organization. ISBN 92-4-154599-2.

2. Al-banna HI, Moha SMS. Compliance to Antihypertensive Treatment and Causes of Partial or Poor Compliance in Patients Attending Ali-Kamal Consultation Center in Suliamania. Zanco J. Med. Sci. 2010;14(Special issue 1):78-84.

3. Al-Dabbagh SA, Aswad SM. Compliance of Hypertensive Patients to Management in Duhok Governorate Using Morisky-Green Test. Duhok Med J. 2010;4(1):28-39.

4. Clark LT. Improving compliance and increasing control of hypertension: Needs of special hypertensive populations. Am Heart J. 1991;121(2):664-9.

5. Al-Sowielem LS, Elzubier A. Compliance and knowledge of hypertensive patients attending PHC centres in Al-Khobar, Saudi Arabia. East Mediterr Health J. 1998;4(2):301-7.

6. Santhanakrishnan I, Lakshminarayanan S, Kar SS. Factors affecting compliance to management of diabetes in Urban Health Center of a ter! tiary care 
teaching hospital of south India. J Nat Sc Biol Med. 2014;5:365-8.

7. Nuesch R, Schroeder K, Dieterle T, Martina B, Battegay E. Relation between insufficient response to antihypertensive treatment and poor compliance with treatment: A prospective case-control study. BMJ. 2001;323:142-6.

8. Constantini L. Compliance, adherence, and selfmanagement: Is a paradigm shift possible for chronic kidney disease clients? CANNT J. 2006;16:4:22-6.

9. Acharya JP, Acharya I. Sociodemographic factors influencing compliance of medication in an urban OPD setting. J Sci Soc. 2014;41:101-7.

10. Morisky DE, Green LW, Levine DM. Concurrent and predictive validity of a self-reported measure of medication adherence. Med Care. 1986;24(1):67-74.

11. Strelec MA, Mion Jr AM. The influence of patient's consciousness regarding high blood pressure and patient's attitude in face of disease controlling medicine intake. Arq Bras Cardiol. 2003;81(4):34954.

12. Linn MW, Linn BS, Stein SR. Satisfaction with ambulatory care and compliance in older patients. Med Care. 1982;20:606-14.

13. Lee VW, Leung PY. Glycemic Control and Medication Compliance in Diabetic Patients in a Pharmacist-Managed Clinic in Hong Kong. Am J Health-Syst Pharm. 2004;60:2593-5.

14. Kalyango JN, Owino E, Nambuya AP. Nonadherence to diabetes treatment at Mulago Hospital in Uganda: Prevalence and associated factors.Afr Health Sci. 2008;8:67-73.

15. Sweileh W, Aker O, Hamooz S. Rate of Compliance among Patients with Diabetes Mellitus and Hypertension. An-Najah Univ J Res. 2005;19:1-12.

16. Hernández-Ronquillo L, Téllez-Zenteno JF, Garduño-Espinosa J, González-Acevez E. Factors associated with therapy noncompliance in type-2 diabetes patients. Salud Publica Mex. 2003;45:191-7.

17. Khattab MS, Abolfotouh MA, Khan MY, Humaidi MA, AlKaldi YM. Compliance and control of diabetes in a family practice setting, Saudi Arabia. East Mediterr Health J. 1999;5:755-65.

18. Spikmans FJ, Brug J, Doven MM, Kruizenga HM, Hofsteenge GH, van Bokhorst-van der Schueren MA. Why do diabetic patients not attend appointments with their dietitian? J Human Nutr Diet. 2003;16:151-8.
19. Kyngas H, Lahdenpera T. Compliance of patients with hypertension and associated factors. J Ad Nurs. 1999;29:832-9.

20. Khan AR, Al-Abdul Lateef ZN, Al Aithan MA, BuKhamseen MA, Al Ibrahim I, Khan SA. Factors contributing to non-compliance among diabetics attending primary health centers in the Al Hasa district of Saudi Arabia. J Fam Community Med. 2012;19:26-32.

21. Ibrahim NK, Attia SG, Sallam SA, Fetohy EM, ElSewi F. Physicians' therapeutic practice and compliance of diabetic patients attending rural primary health care units in Alexandria. J Fam CommunityMed. 2010;17:121-8.

22. Ghods AJ. Nasrollahzadeh D. Noncompliance with Immunosuppressive Medications after Renal Transplantation. Tissue Antigens. 2002;60:553.

23. Mark A, Benjamin W. Tassell V, Joanne L. Medication Nonadherence: An Unrecognized Cardiovascular Risk Factor. MedGenMed. 2007;9(3):58.

24. Senior V, Marteau TM, Weinman J. Self-reported adherence to cholesterol-lowering medication in patients with familial hypercholesterolaemia: The role of illness perceptions. J Cardiovasc Drugs Ther. 2004;18:475-81.

25. Al-Yahya A, Amal M, Al-Ghareeb H. Comparison of Compliance versus Non-Compliance to Antihypertensive Agents in Primary Health Care An Area Based Study. Kuwait Medical Journal. 2006,38(1):28-32.

26. Kasznicki J, Glowacka A, Drzewoski J. Type 2 diabetic patients compliance with drug therapy and glycemic control. Diabetologia Doświadczalna i Kliniczna. 2007;7:199-201.

27. Conlin P, Gerth W, Fox J. Four-year persistence patterns among patients initiating therapy with the angiotensin II receptor antagonist losartan versus other antihypertensive drug classes. Clin Ther. 2001;23:1999-2010.

28. Hadi N, Rostami-Gooran N. Determinant factors of medication compliance in hypertensive patients of Shiraz, Iran. Arch Iranian Med. 2004;7(4):292-6.

Cite this article as: Manasa MR, Preethy JK, Sachin ID. Compliance to prescribed medication among patients in a tertiary care hospital using MoriskyGreen test. Int J Basic Clin Pharmacol 2016;5:21-5. 